\title{
Some anthropological elements in Chekhov's theatre
}

\author{
Bianca Teodorescu \\ University of Craiova, 13 A. I. Cuza Street, Craiova, 200585, Romania \\ E-mail address: bosunpetre@yahoo.com
}

\begin{abstract}
The theatre, an enigmatic world in which the actors can transform for a couple of hours the reality of the spectators in an astonishing universe. Anton Chekhov, Russian dramatist is reveling his magical wings over the creation of the theatre with one of his plays, The Seagull. The time in his plays seems unbearable and it continues endlessly without novelty. One of the character from the theatre play The Seagull is Nina Zarecinaia and represents the single woman in this play that has the power to convert her life. The Chekhov's character, Nina chose to live, love and suffer a manner to win wisdom and to find her way in life. She is more powerful that she thinks and is capable to endure her hard life without giving the possibility to come back to her old home. In this case, she is showing courage to take life as it is. Most important things about this character is that she comes back for a short period and penetrate the quiet space of the other characters, leaving behind at her leaving the appearance of death. Relying on the actions that Nina takes, we can find four elements of anthropology: empathizing, expression patterns, releasing the psychic energies and the art to detect and to avoid the unconscious traps.
\end{abstract}

Keywords: anthropology; incidence of anthopology; theatre

\section{INTRODUCTION}

Theatre is representing a magical institution where the world is handle by the actors that can revive the past stories. The image of theatre is designed as an illusion for our life and it can explain the effects of the phenomena over the spectators.

When people are going to see a play at the theatre, it means that they want an escape from the reality and also to have a good and relaxing time far away from their life. But why do people need this?

With this toxic world, we are affected by stress and others feelings. We learn from school some important ways to escape reality, but also to improve our knowledge: to read a book, to listen to a classical concert or to see a play. The last one can embrace the book and the music too. In the world of theatre, we can participate in a fantasy in which we are absorbed in. 


\section{ANTHROPOLOGICAL INCIDENCE}

Anton Chekhov, a Russian dramatist presents in his play, The Seagull, a world of artists with their romance and conflicts. An interesting fact about this play is that the first production was a failure and only after 1898 became a triumph.

The elements of anthropology exist in any theatre's play. Empathizing, one of the elements of anthropology (Panea, 2001), is an important element in which the actors can understand their in a manner to give the best interpretation in the acts. For example, the character of Nina from The Seagull by Anton Chekhov is a daughter of a harsh landlord:

"My father and his wife never will let me come here; they call this place Bohemia and are afraid I shall become an actress. But this lake attracts me as it does the gulls. My heart is full of you"

and represents an attractive, dreamy and naive woman. The actress who plays Nina must have to understand her change through life, from the naive girl with many to an unsuccessful woman in love and career. Nina is in fact, the seagull, a bird that loves everything, the world, the universe, but someone comes and ruins her life.

The glory that she dreams is just a mirage, like she will find out eventually:

"I know now, I understand at last, Constantine, that for us, whether we write or act, it is not the honour and glory of which I have dreamt that is important, it is the strength to endure. One must know how to bear one's cross, and one must have faith. I believe, and so do not suffer so much, and when I think of my calling I do not fear life."

Is it the effort for the actress to understand Nina? Not really. From the beginning, an actor must learn how to empathize with any types of people and to find what are their motivation to act this way. In this case, what determined Nina to become just a mediocre actress? Maybe she wasn't a very talented artist or just maybe she didn't have luck. The actress that plays Nina has to find what are her weakness and who's fault is in failing in her life. Is it just her's or somebody else?:

"My life used to be as happy as a child's; I used to wake singing in the morning; I loved you and dreamt of fame, and what is the reality? To-morrow morning early I must start for Eltz by train in a third-class carriage, with a lot of peasants, and at Eltz the educated tradespeople will pursue me with compliments. It is a rough life."

Another element of anthropology is represented by the expression patterns (Coman, 2003; Mihăilescu, 2009; Panea, 2012; Panea, 2013). In this case, the actress has to identifiy the elements that distinguish Nina from the rest of the characters. The language of the emotions is universal and any actors can understand them. We can say that this is the advantage of the actors. The expression of patterns follows in the Seagull the difference between the love couple Treplev-Nina and Trigorin-Nina. In the first scenario, the love between Treplev and Nina is more like a childish love, full of dreams and hopes, just a pure love. The relationship advances, but Nina's feelings are transformed and she is not anymore attracted to pure love, instead she follows faime and mediocre intelligence.

The second part of the scenario is shown Nina falling in love with the writer Trigorin. That is the moment when Nina is changing from girl to woman. In this case, Trigorin symbolizes the fame and glory which she is looking for and he represents the perfect man for her to falling in love. Thus, Nina does not understand that fame is not as special as she is seen it: 
"He is the idol of the public, the papers are full of him, his photograph is for sale everywhere, his works have been translated into many foreign languages, and yet he is overjoyed if he catches a couple of minnows. I always thought famous people were distant and proud; I thought they despised the common crowd which exalts riches and birth, and avenged themselves on it by dazzling it with the inextinguishable honour and glory of their fame."

The third element of anthropology is based on releasing the psychic energies. A theatre is more beneficial to the mental state of the actors than a visit to the psychologist (Craig, 2014; Borowski, 2014; Gasderell, 2014). From this, it is resulting that the theatre is equal to psychoanalysis. For an actor, to create a character means to work with the unconscious and the director is the psychoanalyst. The director has to be identified the actor's complex and to exceed the blockage. In the play, The Seagull, the actress who plays Nina has to find her resources from the unconscious and to send the desired energy to the public:

"Why do you say that you have kissed the ground I walked on? You should kill me rather. [She bends over the table] I am so tired. If I could only rest - rest. [She raises her head] I am a sea-gull - no - no, I am an actress. [She hears Arkadina and Trigorin laughing in the distance, runs to the door on the left and looks through the keyhole] He is there too. [She goes back to Treplieff]... Then came all the cares of love, the continual anxiety about my little one, so that I soon grew trivial and spiritless, and played my parts without meaning. I never knew what to do with my hands, and I could not walk properly or control my voice. You cannot imagine the state of mind of one who knows as he goes through a play how terribly badly he is acting. I am a sea-gull - no - no, that is not what I meant to say. Do you remember how you shot a seagull once? A man chanced to pass that way and destroyed it out of idleness. That is an idea for a short story, but it is not what I meant to say."

A great play must have a cathartic effect on the every spectator from the audience. The character Nina and the actress whom is playing has become two souls in one body; annihilating the actress's true self, the director can make the actress to become true Nina.

The last anthropology element is representing the art to detect and to avoid the unconscious traps (Coman, 1999; Burghele, 2000; Hedeșan, 2000). In the world of the theatre, working with the unconscious is very dangerous to their mental state; it is possible to get lost and never find the way back to reality. If an actor is reveling different types of personalities, it could mean to lose his own self. This happened with many actors that applied the Stanislavski's method (to live the emotion, not to interpret it) and went out of their mind.

In Chekhov's Seagull, Nina is showen as a woman who have failed in her love, she didn't formed a family and didn't have succes in career. In the end of the play, Nina is revealing that she is like the seagull, loves the life, but the life does not love her. The love for Trigorin is growing in the last act, but she understands that it is not possible. In the final scene, Nina becomes a wise woman after she accepts the life as it is:

" Hush! I must go. Good-bye. When I have become a famous actress you must come and see me. Will you promise to come? But now - [She takes his hand] it is late. I can hardly stand... No, no - and don't come out, I can find the way alone. My carriage is not far away. So she brought him back with her? However, what difference can that make to me? Don't tell Trigorin anything when you see him. I love him - I love him even more than I used to. It is an idea for a short story. I love him - I love him passionately - I love him to despair. Have you forgotten, Constantine, how pleasant the old times were? What a gay, bright, gentle, pure life we led? How a feeling as sweet and tender as a flower blossomed in our hearts?" 


\section{CONCLUSIONS}

Anton Chekhov presents his play as a way to perceive the reality and implement on the stage the feeling of the actors on the public. The character Nina is the result of the attitude that is designed to persuade the emotions over the audience, she has a dominant feature in the scene in which she appears. As an example of his work, Chekhov wrote: "After all, in real life, people don't spend every moment in shooting one another, hanging themselves, or making declarations of love. They do not spend all their time saying clever things. They are more occupied with eating, drinking, flirting, and saying stupidies. These are the things which ought to be shown on the stage. A play should be written in which people arrive, depart, have dinner, talk about the weather, and play cards. Life must be exactly as it is and people as they are...Let everything on the stage be just as complicated, and at the same time just as simple, as in life. People eat their dinner, just eat their dinner, and all the time their happiness is taking form, or their lives are being destroyed."

\section{References}

[1] Nicolae Panea (2013). Orașul subtil. București: Editura Etnologică.

[2] Andrzej Borowski, International Letters of Social and Humanistic Sciences 14 (2014) 7-17.

[3] Paula Bajdor, Iwona Grabara, Journal of Studies in Social Sciences 7(2) (2014).

[4] D. W. Stacks, M. B. Salwen (Eds.). (2014). An integrated approach to communication theory and research. Routledge.

[5] Knapp, M., Hall, J., \& Horgan, T. (2013). Nonverbal communication in human interaction. Cengage Learning.

[6] Nicolae Panea (2001). Zeii de asfalt, antropologie a urbanului. București: Cartea Românească.

[7] Camelia Burghele (2000). În numele magiei terapeurice. Editura Limes, Zalău.

[8] Nicolae Panea (2012). Antropologie Culturală Americană. Craiova: Editura Universitaria.

[9] Sebastian Kot, Beata Ślusarczyk (2014). IT Role in Supply Chain Collaboration. Current Communication Difficulties, 165.

[10] Otilia Hedeșan (2000). Pentru o miologie difuză. Timișora: Editura Marineasa.

[11] Mihai Coman (1999). Introducere în sistemul mass-media. Polirom.

[12] Alan Barnard, Jonathan Spencer (2002) (Ed.). Encyclopedia of Social and Cultural Anthropology. London \& New York: Routledge.

[13] Florentin Smarandache, Stefan Vladutescu, Revista de Cercetare şi Intervenţie Socială, 46 (2014) 243-254.

[14] Vintilă Mihăilescu (2009). Antropologie: cinci introduceri. Polirom. 
[15] Aurelia Traistaru (2013). Consolidation of the green marketing profile in current austerity period. Jokull.

[16] Mihai Coman, Media anthropology (2005) 46-55.

[17] Ştefan Vlăduţescu, European Scientific Journal 9(32) (2013).

[18] Mihai Coman (1999). Introducere în sistemul mass-media. Polirom.

[19] Andrzej Borowski, International Letters of Social and Humanistic Sciences 4 (2013) $70-74$.

[20] Bartłomiej Okwiet, Alina Țenescu, Adrian Nicolescu (2014). Social, communicational and law responsibility in multinational companies. Topical Communication Uncertainties, 149.

[21] J. H. Gasderell, International Letters of Social and Humanistic Science 22 (2014) 85-91.

[22] Ștefan Vlăduțescu, Florentin Smarandache, Daniela Gîfu, Alina Țenescu (2014). Topical Communication Uncertainties. Craiova/Columbus: Sitech/Zip Publishing.

[23] Mihai Coman (2003). Mass-media, mit și ritual. Iași: Editura Polirom.

[24] Ştefan Vlăduţescu, American International Journal of Contemporary Research 3(10) (2013).

[25] Andrzej Borowski, International Letters of Social and Humanistic Sciences 14 (2014) 33-41.

[26] Ștefan Vlăduțescu, International Letters of Social and Humanistic Sciences 10 (2014) 100-106.

[27] Andrzej Borowski, International Letters of Social and Humanistic Sciences 6 (2013) 86-90.

[28] Janusz Grabara, Michal Kolcun, Sebastian Kot, International Journal of Education and Research 2(2) (2014).

[29] G. Rajović, J. Bulatović, International Letters of Social and Humanistic Sciences 6 (2013) 24-35.

[30] S. M. Radu, International Letters of Social and Humanistic Sciences 16 (2014) 184-193.

[31] Florentin Smarandache, Ștefan Vlăduțescu, Alina Țenescu (2014). Current Communication Difficulties. Craiova/Columbus: Sitech/Zip Publishing.

[32] Andrzej Borowski, International Letters of Social and Humanistic Sciences 14 (2014) $7-17$.

[33] Max G. Craig, Journal of Studies in Social Sciences 8(1) (2014).

[34] Jason L. Powell, International Letters of Social and Humanistic Sciences 17(1) (2014) $1-60$. 